\title{
PENINGKATAN AKTIVITAS DAN KEMAMPUAN MENALAR SISWA MELALUI MODEL PEMBELAJARAN SIKLUS BELAJAR 5E
}

\author{
Presilia Aditya Perta $^{1^{*}}$, Irwandi Ansori ${ }^{1}$, dan Bhakti Karyadi ${ }^{1}$ \\ ${ }^{1}$ Program Studi Pendidikan Biologi, Fakultas Keguruan dan Ilmu Pendidikan, Universitas Bengkulu \\ Email :presiliaferta@yahoo.com
}

\begin{abstract}
Abstrak
Penelitian ini bertujuan untuk meningkatkan aktivitas dan kemampuan menalar siswa kelas XI IPA 1 SMAN 1 Kota Bengkulu melalui model pembelajaran Siklus Belajar 5E. Jenis penelitian ini termasuk dalam penelitian tindakan kelas dengan metode deskriptif. Penelitian terdiri dari dua siklus, setiap siklus terdiri dari 4 tahap yaitu perencanaan, pelaksanaan, pengamatan dan refleksi. Subyek penelitian ini adalah siswa kelas XI IPA 1 SMAN 1 Kota Bengkulu tahun ajaran 2016/2017 yang berjumlah 31 orang. Instrumen yang digunakan berupa lembar observasi aktivitas siswa, dan lembar tes kemampuan menalar siswa. Analisis data dilakukan secara deskriptif dengan menghitung rerata skor dan menentukan kriteria aktivitas dan kemampuan menalar siswa. Hasil penelitian menunjukkan bahwa rerata skor aktivitas siswa pada siklus I sebesar 2,9 (Baik), dan pada siklus II meningkat menjadi 3,0 (Baik). Rerata skor kemampuan menalar siswa pada siklus I yaitu 76,41 (Cukup), dan pada siklus II meningkat menjadi 85,48 (Baik). Kesimpulan dari hasil penelitian ini adalah penerapan model Siklus Belajar 5E dapat meningkatkan aktivitas dan kemampuan menalar siswa kelas XI IPA 1 SMAN 1 Kota Bengkulu pada materi Sistem Ekskresi.
\end{abstract}

Kata Kunci: aktivitas siswa, kemampuan menalar, model siklus belajar 5E

\begin{abstract}
This research aimed to improve the students activities and the students reasoning skills in class XI IPA 1 SMAN 1 Bengkulu City by using Learning Cycle $5 E$ Model. This research is classroom action research with descriptive method. The research consist of two cycles, each cycle consist of four phases: planning, implementation, observation and reflection. The subject of this research was the students of class XI IPA 1 SMAN 1 Bengkulu City academic year 2016/2017. The instruments used in this research were the observation sheet of students activities, and the written test sheet of students reasoning skill. The analysis of the data was conducted descriptively by calculating the average score and determining the criteria of students activities and students reasoning skills. The results of this research showed that the average score of students activities in the first cycle is 2,9 (good criteria), and in the second cycle the students activities score increased to 3,0 (good criteria). The average score of the students reasoning skill in the first cycle is 76,41 (sufficiency criteria), and in the second cycle increased to 85,48 (good criteria). The conclution of this research is an application of the Learning Cycle 5E Model can increase the students activities and the students reasoning skills in class XI IPA 1 SMAN 1 Bengkulu City in the Excretion System Material.
\end{abstract}

Keywords: the students activities, reasoning skills, learning cycle $5 \mathrm{E}$ model 


\section{PENDAHULUAN}

Memasuki Abad ke-21, sistem pendidikan nasional menghadapi tantangan yang sangat kompleks dalam menyiapkan kualitas sumber daya manusia (SDM) yang mampu bersaing di era global (Tabany, 2014). Salah satu keterampilan atau kemampuan yang dibutuhkan peserta didik untuk mampu bersaing di Abad 21 adalah kemampuan menalar.

Kemampuan menalar adalah kemampuan berpikir yang logis dan sistematis atas fakta-fakta empiris yang dapat diobservasi untuk memperoleh simpulan berupa pengetahuan. Pada kegiatan menalar, siswa akan menghubungkan apa yang sedang dipelajari dengan apa yang ada dalam kehidupan sehari-hari (Hosnan, 2014). Kemampuan menalar sangat penting untuk dikuasai karena tuntutan pada abad 21 menuntut siswa untuk menguasai $4 \mathrm{C}$ yaitu keterampilan abad 21 yang meliputi Creative, Critical thinking, Communicative, dan Collaborative. Brookhart (2010) dalam Arifin (2017) menyebutkan bahwa yang termasuk berpikir kritis (critical thinking) salah satunya adalah penalaran (reasoning).

Berdasarkan hasil wawancara yang dilakukan peneliti terhadap guru mata pelajaran biologi kelas XI IPA 1 SMAN 1 Kota Bengkulu, dari 31 orang siswa di kelas XI IPA 1 hanya 19 orang siswa yang mencapai KBM untuk mata pelajaran Biologi yang telah ditentukan sekolah yaitu 75. Sejumlah siswa masih mengalami kesulitan dalam memahami konsep, menginterpretasi dan menganalisis data hasil percobaan, serta masih kesulitan jika diminta menjelaskan tentang suatu permasalahan atau fenomena yang ditunjukkan guru. Hal ini dikarenakan siswa belum mendayagunakan kemampuan menalarnya dengan optimal dalam kegiatan pembelajaran. Faktor yang menyebabkan belum optimalnya pendayagunaan kemampuan menalar siswa adalah kegiatan pembelajaran yang dilakukan oleh guru belum banyak menekankan aktivitas belajar dan aktivitas berpikir siswa sehingga siswa kurang berpartisipasi aktif dalam proses pembelajaran untuk mengembangkan kemampuan menalarnya.

Kemampuan menalar siswa diharapkan dapat meningkat jika siswa mampu mengkonstruk atau membangun pengetahuannya sendiri melalui pemahaman yang mendalam. Proses pembelajaran harus mampu melibatkan siswa untuk berpartisipasi aktif, bukan hanya mentransfer pengetahuan dari guru ke siswa saja. Proses pembelajaran yang melibatkan siswa untuk berpartisipasi aktif akan melibatkan prosesproses kognitif yang potensial dalam merangsang perkembangan intelek siswa. Salah satu proses pembelajaran yang dapat melibatkan aktivitas dan proses kognitif siswa ialah proses pembelajaran dengan model Siklus Belajar 5E.

Kegiatan pembelajaran dengan model Siklus Belajar 5E terdiri dari tahap engagement (pelibatan), exploration (penyelidikan), explanation (penjelasan), elaboration (penggalian), dan evaluation (evaluasi) (Collette dan Chiappetta, 1994 dalam Firdaus, dkk, 2016).

Model Siklus Belajar 5E merupakan model pembelajaran yang berpusat pada siswa, dan didasarkan pada pandangan konstruktivisme sehingga dapat menciptakan pembelajaran di mana siswa aktif untuk mencari dan mengkonstruksi pengetahuannya sendiri (Hartati, dkk, 2015). Pembelajaran dengan model Siklus Belajar 5E berbasis pada penyelidikan. Menurut Schen (2007) dalam Daryanti, dkk (2015), penyelidikan pada saat proses pembelajaran dapat memfasilitasi siswa memperoleh pengetahuan ilmiah melalui penalaran berdasarkan pada bukti yang diperoleh. Pembelajaran dengan model Siklus Belajar 5E dapat meningkatkan kemampuan menalar siswa. 
Pembelajaran Biologi pada materi Sistem Ekskresi dapat dilaksanakan dengan menggunakan model Siklus Belajar 5E. Kompetensi Dasar (KD) pada materi Sistem Ekskresi di kelas XI semester 2 juga menuntut siswa terampil berpikir mendalam atau menalar, yaitu KD 3.9 Menganalisis hubungan antara struktur jaringan penyusun organ pada sistem ekskresi dalam kaitannya dengan bioproses dan gangguan fungsi yang dapat terjadi pada sistem ekskresi manusia (Permendikbud Nomor 24 Tahun 2016 tentang KI dan KD Pelajaran pada K13 pada Pendidikan Dasar dan Pendidikan Menengah).

Tujuan penelitian ini adalah untuk meningkatkan aktivitas dan kemampuan menalar siswa kelas XI IPA 1 SMAN 1 Kota Bengkulu pada materi Sistem Ekskresi melalui penerapan model pembelajaran Siklus Belajar 5E.

\section{METODE}

Penelitian ini merupakan Penelitian Tindakan Kelas (PTK) dengan metode deskriptif yang dilakukan dalam 2 kali siklus, setiap siklus terdiri tahap perencanaan, pelaksanaan, pengamatan dan refleksi (Kunandar, 2011). Penelitian dilaksanakan pada semester genap tahun ajaran 2016/2017 di SMAN 1 Kota Bengkulu. Peran peneliti dalam penelitian ini adalah sebagai guru biologi yang mengajar siswa pada materi Sistem Ekskresi. Guru dibantu oleh 3 orang observer yang mengobservasi aktivitas siswa dalam kegiatan pembelajaran dengan model Siklus Belajar 5E.

Subjek penelitian yaitu siswa kelas XI IPA 1 berjumlah 31 siswa yang terdiri dari 25 siswa perempuan dan 6 siswa laki-laki.

Teknik pengumpulan data dalam penelitian ini adalah observasi dan tes. Instrumen yang digunakan berupa lembar observasi aktivitas siswa dan lembar tes menalar. Lembar observasi aktivitas siswa digunakan untuk mengobservasi aktivitas siswa dalam kegiatan pembelajaran dengan model Siklus Belajar 5E. Lembar tes menalar terdiri dari soal-soal uraian yang digunakan untuk mengukur kemampuan menalar siswa. Soal-soal uraian pada lembar tes dirumuskan berdasarkan indikator kemampuan menalar yang telah ditentukan dalam penelitian ini, yaitu kemampuan untuk memberikan alasan, merekam hasil observasi, menggunakan bukti-bukti yang benar, menyatakan tafsiran, mengonstruksi argumen, dan menarik kesimpulan dari hasil menyelidiki. Keenam indikator tersebut dikelompokkan menjadi dua aspek dalam kemampuan menalar, yaitu aspek membangun keterampilan dasar, dan memberikan penjelasan lanjut (Ennis, 1985 dalam Muhfahroyin, 2009).

Data hasil observasi aktivitas siswa dianalisis dengan rerata skor dan kategori rerata skor.

Kategori rerata skor aktivitas siswa terdiri dari 3 kategori, yaitu Baik, Cukup, dan Kurang. Kisaran skor untuk tiap kategori ditentukan dengan rumus berikut (Susanti, 2010).

Keterangan:

$$
\text { Kisaran skor }=\frac{X_{n}-X_{1}}{k}
$$

$X_{n}=$ Skor maksimum

$X_{1}=$ Skor minimum

$k$ = Jumlah kategori

Kategori rerata skor aktivitas siswa dapat dilihat pada Tabel 1.

Tabel 1. Kategori Rerata Skor Aktivitas Siswa

\begin{tabular}{|c|c|}
\hline Rerata Skor & Kategori \\
\hline $2,4-3,0$ & Baik \\
\hline $1,7-2,3$ & Cukup \\
\hline $1,0-1,6$ & Kurang \\
\hline
\end{tabular}

Data kemampuan menalar siswa dianalisis dengan rerata skor, kategori rerata skor, persentase ketercapaian tiap aspek kemampuan menalar, dan persentase tiap kategori predikat skor kemampuan menalar. 
Kategori kemampuan menalar siswa terdiri dari 4 kategori, yaitu Sangat Baik (A), Baik (B), Cukup (C), dan Kurang (D).

Penentuan kisaran skor tiap kategori kemampuan menalar siswa didasarkan pada panduan penilaian yang ditetapkan oleh Direktorat Pembinaan Sekolah Menengah Atas (2017), yaitu rentang predikat atau kategori dapat ditentukan dengan rumus berikut.

Rentang Predikat $=\frac{\text { nilai } \text { maksimum }- \text { KBM }}{\text { jumlah predikat di luar } D}$

\section{HASIL DAN PEMBAHASAN}

Berdasarkan hasil penelitian yang telah dilakukan, data hasil observasi aktivitas siswa dalam kegiatan pembelajaran dengan model Siklus Belajar 5E dapat dilihat pada Tabel 3. Data pada Tabel 3 menunjukkan bahwa
Nilai KBM 75 yang ditetapkan SMAN 1 Kota Bengkulu merupakan nilai minimum untuk kategori Cukup (C). Kategori kemampuan menalar dapat dilihat pada Tabel 2.

Tabel 2. Kategori Kemampuan Menalar

\begin{tabular}{cc}
\hline Skor & Kategori \\
\hline $91 \leq A \leq 100$ & Sangat Baik \\
$83 \leq B<91$ & Baik \\
$75 \leq C<83$ & Cukup \\
$<75$ & Kurang \\
\hline
\end{tabular}

rerata skor aktivitas siswa mengalami peningkatan dari siklus I ke siklus II. Pada siklus I, rerata skor aktivitas siswa sebesar 2,9 dengan kategori baik, dan pada siklus II mengalami peningkatan menjadi 3,0 dengan kategori baik.

Tabel 3. Rerata Skor dan Kategori Aktivitas Guru

\begin{tabular}{ccc}
\hline Siklus & Rerata Skor & Kategori \\
\hline I & 2,9 & Baik \\
II & 3,0 & Baik
\end{tabular}

Proses pembelajaran dengan model Siklus Belajar 5E terdiri dari 5 tahap, yaitu Engagement, Exploration, Explanation, Elaboration, dan Evaluation (Collette dan Chiappetta, 1994 dalam Firdaus, dkk, 2016).

Hasil penelitian menunjukkan bahwa pada siklus I walaupun aktivitas siswa telah menunjukkan kategori baik, tetapi aktivitas siswa pada tahap Exploration dan Evaluation dinilai masih belum optimal. Pada tahap Exploration aktivitas siswa memperoleh rerata skor 2,88 sedangkan pada tahap Evaluation memperoleh rerata skor 2,66. Rerata skor aktivitas siswa dalam setiap tahapan pembelajaran dengan model Siklus Belajar 5E dapat dilihat pada Tabel 4.

Tabel 4. Rerata Skor Aktivitas Siswa pada Setiap Tahapan Model Siklus Belajar 5E

\begin{tabular}{cccc}
\hline Tahap SB 5E & Siklus I & Siklus II & Keterangan \\
\hline Engagement & 3,0 & 3,0 & Meningkat \\
Exploration & 2,88 & 3,0 & \\
Explanation & 3,0 & 3,0 & Meningkat \\
Elaboration & 3,0 & 3,0 & \\
Evaluation & 2,66 & 3,0 & \\
\hline
\end{tabular}

Pada tahap Exploration, kekurangan yang ditemukan yaitu hanya 4 kelompok dari 6 kelompok siswa yang memperhatikan penjelasan prosedur kegiatan percobaan tentang identifikasi zat sisa yang dikeluarkan oleh paru-paru yang disampaikan oleh guru. Hal ini disebabkan oleh upaya guru dalam memotivasi siswa untuk melakukan 
penyelidikan masih belum optimal. Masalah yang disajikan guru belum dapat memancing rasa ingin tahu siswa untuk belajar sehingga siswa kurang antusias dalam memperhatikan penjelasan prosedur kegiatan percobaan yang disampaikan oleh guru.

Sedangkan pada tahap Evaluation, kekurangan yang ditemukan yaitu masih sedikit siswa yang terlibat aktif dalam kegiatan diskusi kelompok dalam menarik kesimpulan berdasarkan kegiatan pembelajaran yang telah dilakukan. Hal ini terlihat saat proses pembelajaran yaitu hanya 3 kelompok yang menarik kesimpulan dari kegiatan percobaan tentang identifikasi zat sisa yang dikeluarkan oleh paru-paru berdasarkan hasil kerja sama atau diskusi seluruh anggota kelompoknya. Sedangkan pada 3 kelompok lainnya, kegiatan diskusi dalam menarik kesimpulan dari kegiatan percobaan tentang identifikasi zat sisa yang dikeluarkan oleh paru-paru hanya didominasi oleh beberapa anggota kelompok yang memiliki kemampuan akademik tinggi, sedangkan anggota kelompok yang kemampuan akademiknya sedang dan rendah belum menunjukkan partisipasinya. Hal ini disebabkan oleh belum optimalnya upaya guru dalam membimbing kegiatan diskusi kelompok. Guru belum membimbing seluruh kelompok dalam berdiskusi menarik kesimpulan, hal ini dikarenakan penggunaan waktu pembelajaran yang sudah melebihi alokasi waktu yang telah ditentukan.

Berdasarkan kekurangan-kekurangan yang ditemukan tersebut, guru merencanakan perbaikan untuk meningkatkan aktivitas siswa pada siklus II. Hal ini sesuai dengan pendapat Yudhistira (2013) yang menyatakan bahwa untuk menciptakan pembelajaran yang bermutu, guru harus terus melakukan perbaikan pembelajaran dengan cara melakukan refleksi dan introspeksi terhadap pembelajaran yang telah dilakukannya.

Pada siklus II, guru berupaya untuk memberikan motivasi kepada siswa melalui pertanyaan-pertanyaan yang dapat mem- bangkitkan rasa ingin tahu dan antusisme siswa, serta mempertimbangkan dengan baik penggunaan alokasi waktu pembelajaran agar dapat membimbing kegiatan diskusi pada seluruh kelompok. Perbaikan yang dilakukan guru didasarkan pada hasil refleksi kegiatan pembelajaran dan saran yang diajukan oleh para observer. Hal ini didukung oleh pendapat Gachy (2011) dalam Purwanto (2014) yang menyatakan bahwa model Siklus Belajar menuntut kesungguhan dan kreativitas guru, memerlukan pengelolaan kelas yang lebih terencana dan terorganisasi, serta memerlukan waktu dan tenaga yang lebih banyak dalam melaksanakan pembelajaran.

Upaya guru untuk memotivasi dan membimbing siswa bertujuan untuk mendorong siswa terlibat aktif dalam kegiatan pembelajaran dan mendayagunakan kemampuan menalarnya. Hal ini didukung oleh pendapat Lestari (2011) yang menyatakan bahwa keaktifan siswa dapat terwujud jika di dalam kelas siswa dituntut aktif ikut terlibat langsung dalam proses pembelajaran.

Upaya guru untuk melakukan perbaikan menyebabkan peningkatan rerata skor aktivitas siswa di siklus II menjadi 3,0 yaitu dengan kategori baik. Pada siklus II, seluruh siswa sudah terlibat aktif dalam proses pembelajaran. Rerata skor pada tahap Exploration mengalami peningkatan menjadi 3,0. Hal ini dikarenakan upaya guru dalam memotivasi siswa untuk melakukan penyelidikan telah optimal. Masalah yang disajikan guru dapat memancing rasa ingin tahu siswa untuk belajar sehingga seluruh kelompok siswa antusias memperhatikan penjelasan prosedur kegiatan percobaan tentang identifikasi sifat fisik dan kandungan urin manusia yang disampaikan oleh guru. Rerata skor pada tahap Evaluation juga mengalami peningkatan menjadi 3,0. Seluruh siswa terlibat aktif dalam kegiatan diskusi kelompok dalam menarik kesimpulan berdasarkan kegiatan pembelajaran yang 
telah dilakukan. Hal ini terlihat saat proses pembelajaran yaitu seluruh kelompok menarik kesimpulan dari kegiatan percobaan tentang identifikasi sifat fisik dan kandungan urin manusia berdasarkan hasil kerja sama atau diskusi seluruh anggota kelompoknya. Hal ini disebabkan oleh upaya guru dalam membimbing kegiatan diskusi pada seluruh kelompok telah optimal.
Peningkatan aktivitas siswa diikuti dengan peningkatan kemampuan menalar siswa. Hal ini didukung oleh pendapat Pratiwi (2016) yang menyatakan bahwa peningkatan aktivitas guru dan aktivitas siswa dengan penerapan model Siklus Belajar 5E berdampak terhadap peningkatan hasil belajar siswa. Data kemampuan menalar siswa dapat dilihat pada Tabel 5.

Tabel 5. Rerata Skor dan Kategori Kemampuan Menalar Siswa

\begin{tabular}{ccc}
\hline Siklus & Rerata Skor & Kategori \\
\hline I & 76,41 & Cukup \\
II & 85,48 & Baik \\
\hline
\end{tabular}

Hasil penelitian menunjukkan bahwa kemampuan menalar siswa mengalami peningkatan dari siklus I ke siklus II. Pada siklus I, rerata skor kemampuan menalar siswa adalah 76,41 dengan kategori cukup. Sedangkan pada siklus II meningkat menjadi 85,48 dengan kategori baik.

Pada siklus I kemampuan menalar siswa masih berada pada kategori cukup dengan rerata skor 76,41, masih banyak siswa yang belum memiliki kemampuan dalam memberikan bukti-bukti yang benar sebagai pendukung argumen yang diajukan pada saat mengerjakan soal tes. Hal ini terlihat dari rendahnya persentase ketercapaian aspek membangun keterampilan dasar seperti yang dapat dilihat pada Tabel 6, yaitu baru mencapai $73,3 \%$. Salah satu indikator kemampuan menalar dari aspek membangun keterampilan dasar adalah menggunakan bukti-bukti yang benar.

Sedangkan pada aspek memberikan penjelasan lanjut, persentase ketercapaiannya sudah cukup memuaskan yaitu sebesar 83,9\% (Tabel 6). Siswa dinilai sudah cukup terampil dalam memberikan alasan dengan mengonstruksi argumen, menyatakan tafsiran, dan menarik kesimpulan.

Jika dihubungkan dengan kegiatan pembelajaran dengan model Siklus Belajar $5 \mathrm{E}$, pada siklus I antusisme beberapa kelompok siswa terhadap proses pembelajaran masih rendah. Hal ini disebabkan oleh upaya guru dalam memotivasi siswa untuk melakukan penyelidikan masih belum optimal. Masalah yang disajikan guru belum dapat memancing rasa ingin tahu siswa untuk belajar sehingga siswa kurang antusias dalam memperhatikan penjelasan prosedur kegiatan percobaan yang disampaikan oleh guru. Selain itu, pada beberapa kelompok kegiatan diskusi dalam menarik kesimpulan dari kegiatan percobaan hanya didominasi oleh beberapa anggota kelompok yang memiliki kemampuan akademik tinggi, sedangkan anggota kelompok yang kemampuan akademiknya sedang dan rendah belum menunjukkan partisipasinya.

Tabel 6. Persentase Ketercapaian Aspek Kemampuan Menalar Siswa

\begin{tabular}{cccc}
\hline \multirow{2}{*}{ Aspek Kemampuan Menalar } & \multicolumn{2}{c}{ \% Ketercapaian } & \multirow{2}{*}{ Keterangan } \\
\cline { 2 - 3 } & Siklus I & Siklus II & \\
\hline Membangun keterampilan dasar & 73,3 & 86 & Meningkat \\
Memberikan penjelasan lanjut & 83,9 & 84,3 & Meningkat \\
\hline Rata-rata & 78,6 & 85,15 & Meningkat \\
\hline
\end{tabular}


Upaya guru untuk melakukan perbaikan menyebabkan siswa terlibat aktif dalam kegiatan pembelajaran dan mendayagunakan kemampuan menalarnya dalam membangun pengetahuan. Hal ini dapat dilihat dari adanya peningkatan rerata skor kemampuan menalar siswa pada siklus II menjadi 85,48 dengan kategori baik. Persentase aspek kemampuan menalar siswa juga mengalami peningkatan. Peningkatan tertinggi terdapat pada aspek membangun keterampilan dasar yaitu sebesar $12,7 \%$ dari siklus I ke siklus II. Sedangkan aspek memberikan penjelasan lanjut hanya menunjukkan peningkatan sebesar $0,4 \%$ dari siklus I ke siklus II.

Pada siklus II, kemampuan menalar siswa sudah lebih baik, hal ini terlihat dari meningkatnya kemampuan siswa dalam memberikan alasan, mengonstruksi argumen, menggunakan bukti-bukti yang benar, merekam hasil observasi, menyatakan tafsiran, dan menarik kesimpulan.

Peningkatan kemampuan menalar siswa juga dapat dilihat dari persentase kemampuan menalar siswa pada setiap kategori (Tabel 7). Secara berturut-turut, persentase kemampuan menalar siswa di siklus I pada kategori Sangat Baik, Baik, Cukup, dan Kurang yaitu 6,45\%; 22,58\%; 48,38\%; dan 22,58\%. Pada siklus II, persentase kemampuan menalar siswa pada kategori Sangat Baik dan Baik mengalami peningkatan menjadi $29 \%$ dan $58 \%$, sedangkan pada kategori Cukup dan Kurang, keduanya mengalami penurunan menjadi $6,45 \%$.

Tabel 7. Persentase Kategori Kemampuan Menalar Siswa

\begin{tabular}{ccccc}
\hline \multirow{2}{*}{ Siklus } & \multicolumn{4}{c}{ Persentase Kemampuan Menalar (\%) } \\
\cline { 2 - 5 } & Sangat Baik & Baik & Cukup & Kurang \\
\hline I & 6,45 & 22,58 & 48,38 & 22,58 \\
II & 29 & 58 & 6,45 & 6,45 \\
\hline
\end{tabular}

Pada siklus II, guru lebih mengoptimalkan upaya memotivasi siswa agar siswa antusias untuk terlibat aktif dalam kegiatan pembelajaran, serta mengoptimalkan upaya membimbing kegiatan diskusi pada tiap-tiap kelompok. Merujuk pada pendapat yang dikemukakan Wena (2014), jika tahapan-tahapan pembelajaran model Siklus Belajar 5E dirancang dengan baik oleh guru maka motivasi belajar siswa akan meningkat. Meningkatnya motivasi belajar siswa tentu dapat mendorong peningkatan hasil belajar siswa.

Pada penelitian ini, di tahap pelibatan (engagement) siswa dilibatkan secara langsung melalui beberapa pertanyaan yang berhubungan dengan kehidupan sehari-hari. Merujuk pada pendapat Asna (2016), bahwa tujuan dari tahapan ini adalah mendorong siswa untuk memahami pertanyaan atau permasalahan yang ada dan bagaimana cara memecahkannya. Pada siklus I pertanyaan yang diajukan guru kepada siswa adalah mengenai konsep sistem ekskresi pada paruparu, sedangkan pertanyaan di siklus II mengenai konsep sistem ekskresi pada ginjal. Selanjutnya siswa diberi kesempatan untuk membuat prediksi atau memberikan jawaban sementara dari pertanyaan tersebut. Tahapan ini dapat melatih kemampuan menalar siswa dalam mengonstruksi argumen. Kemampuan mengonstruksi argumen merupakan kemampuan siswa dalam mengemukakan pendapat atau pandangannya dalam menjawab pertanyaan yang diajukan oleh guru disertai dengan alasan yang logis. 
Pada tahap penyelidikan (exploration) siswa mencari dan mengumpulkan data atau informasi untuk memecahkan masalah terkait pertanyaan yang diajukan guru pada tahap engagement (pelibatan) dengan melakukan eksperimen. Pada siklus I siswa melakukan eksperimen tentang identifikasi zat sisa yang dikeluarkan oleh paru-paru, sedangkan pada siklus II siswa melakukan eksperimen tentang identifikasi sifat fisik dan kandungan urin manusia. Tahapan ini dapat melatih kemampuan menalar siswa dalam merekam hasil observasi yaitu berupa pembuatan tabel atau grafik untuk melaporkan data hasil eksperimen yang diperoleh siswa. Tabel atau grafik tersebut dirancang sendiri oleh siswa berdasarkan hasil pemikirannya. Menurut Asna (2016), investigasi informasi yang relevan terkait dengan permasalahan yang diajukan akan memberikan kemampuan kepada siswa untuk menemukan sendiri jawabannya dan berpikir secara logis dan rasional. Hal ini akan meningkatkan kemampuan menalar siswa.

Pada tahap penjelasan (explanation) siswa menjelaskan temuan yang diperoleh dari hasil penyelidikan yang telah dilakukan. Tahapan ini melatih kemampuan menalar siswa dalam mengonstruksi argumen, memberikan alasan, menggunakan buktibukti yang benar dalam membangun argumen, menyatakan tafsiran atau memaknai data yang ada di dalam tabel dan grafik, serta menarik kesimpulan dari hasil penyelidikan mengenai identifikasi zat sisa yang dikeluarkan oleh paru-paru di siklus I dan penyelidikan tentang identifikasi sifat fisik dan kandungan urin manusia di siklus II, sehingga siswa memperoleh konsep yang mendalam dari hasil temuan yang diperolehnya. Sebagaimana dijelaskan oleh Hosnan (2014) bahwa menalar meliputi proses berpikir yang logis dan sistematis atas fakta-fakta empiris yang dapat diobservasi untuk memperoleh simpulan berupa pengetahuan. Pada tahap ini kegiatan yang dilakukan guru adalah membimbing siswa dalam memperoleh konsep agar siswa terhindar dari miskonsepsi.

Pada tahap penggalian (elaboration) siswa diberikan pertanyaan dengan konteks yang berbeda untuk mengaplikasikan pengetahuan yang diperolehnya, hal ini melatih menalar siswa dalam menghubungkan suatu topik dengan topik yang lain. Sesuai dengan pendapat Hosnan (2014) yang menyatakan bahwa kegiatan menalar dilakukan untuk menemukan keterkaitan satu informasi dengan informasi lainnya, atau menghubungkan apa yang sedang dipelajari dengan apa yang ada dalam kehidupan sehari-hari.

Tahap terakhir dari model Siklus Belajar 5E adalah tahap evaluasi (evaluation), tahap ini bertujuan untuk mengecek pemahaman siswa terhadap konsep yang telah dipelajari. Pada tahap evaluasi siswa menggunakan semua indikator kemampuan menalar agar siswa dapat mengevaluasi kelebihan dan kekurangannya dalam kegiatan pembelajaran.

Faktor lain yang berperan dalam mendorong peningkatan kemampuan menalar siswa selain aktivitas belajar siswa adalah bimbingan dari guru. Merujuk pada pendapat Krajcik dan Czerniak (2014) bahwa menyusun penjelasan ilmiah yang mencakup penalaran tidak mudah bagi siswa dan membutuhkan latihan yang rutin. Sehingga peranan guru dalam membimbing siswa ketika proses pembelajaran berlangsung sangat diperlukan guna meningkatan kemampuan menalar siswa. Hal ini sesuai dengan pendapat Faizah (2010) yang menyatakan bahwa bimbingan berperan dalam membantu siswa untuk mengatasi kesulitan atau kesukaran mereka dalam proses belajar di kelas sehingga siswa mampu untuk meningkatkan prestasinya. Bimbingan yang baik dilakukan agar penalaran siswa bisa lebih baik lagi. 
Berdasarkan hasil penelitian, dapat disimpulkan bahwa model Siklus Belajar 5E dapat meningkatkan aktivitas dan kemampuan menalar siswa pada materi Sistem Ekskresi. Hasil penelitian ini didukung oleh hasil penelitian Putri (2016) yang menyimpulkan bahwa penerapan model pembelajaran Learning Cycle 5E dapat meningkatkan kemampuan penalaran dan pemahaman konsep siswa.

Tahapan-tahapan dari model Siklus Belajar 5E mengarahkan proses pembelajaran agar berpusat kepada siswa (student center) sehingga siswa aktif mencari dan mengkonstruksi pengetahuannya sendiri, dengan demikian siswa diberi kesempatan untuk mengembangkan kemampuan menalar di setiap tahap pembelajarannya melalui pelibatan prosesproses kognitif yang potensial dalam merangsang perkembangan intelek siswa. Hal ini didukung oleh pendapat Hartati, dkk (2015) yang menyatakan bahwa model Siklus Belajar 5E merupakan model pembelajaran yang berlandaskan paham konstruktivisme sehingga dapat menciptakan pembelajaran di mana siswa aktif untuk mencari dan mengkonstruksi pengetahuannya sendiri.

Proses pembelajaran dengan model Siklus Belajar 5E bukan sekedar transfer pengetahuan dari guru ke siswa, tetapi merupakan proses pemerolehan konsep yang berorientasi pada keterlibatan siswa secara aktif dan langsung. Berbeda halnya dengan pembelajaran konvensional yang lebih cenderung teacher centered, sehingga mengakibatkan daya berpikir siswa tidak berkembang dengan baik. Hal ini didukung oleh pendapat Asna (2016) yang menyatakan bahwa hasil pembelajaran konvensional mengakibatkan siswa hanya terbatas mengingat konsep-konsep dari materi pelajaran yang disampaikan oleh guru tetapi tidak memahami untuk apa konsep tersebut dipelajari.

\section{PENUTUP}

\section{Simpulan}

Penerapan model pembelajaran Siklus Belajar 5E dapat meningkatkan aktivitas dan kemampuan menalar siswa kelas XI IPA 1 SMAN 1 Kota Bengkulu pada materi Sistem Ekskresi. Hal ini terlihat dari rerata skor aktivitas siswa yang diperoleh pada siklus I sebesar 2,9 (Baik), dan pada siklus II mengalami peningkatan menjadi 3,0 (Baik). Peningkatan aktivitas siswa diikuti dengan peningkatan kemampuan menalar siswa. Hal ini terlihat dari rerata skor kemampuan menalar siswa pada siklus I yaitu 76,41 (Cukup), dan pada siklus II mengalami peningkatan menjadi 85,48 (Baik).

\section{Saran}

Berdasarkan hasil penelitian yang telah dilakukan, maka disarankan bagi guru atau bagi peneliti selanjutnya bahwa perlu dilakukan penelitian dengan mengukur kemampuan berpikir tingkat tinggi siswa.

\section{DAFTAR PUSTAKA}

Arifin, Z. 2017. Mengembangkan Instrumen Pengukur Critical Thinking Skills Siswa pada Pembelajaran Matematika Abad 21. Jurnal THEOREMS (The Original Research of Mathematics), (Online), Vol. 1, No. 2, Hal. 92-100, (http://jurnal.unma.ac.id, diakses 5 Februari 2017).

Asna, R. H. 2016. Implementasi Strategi Pembelajaran Berbasis Inkuiri dengan Siklus Belajar 5E untuk Meningkatkan Keterampilan Berpikir Kritis. Jurnal Penelitian Pendidikan, (Online), ISSN 1412-565 X, Hal. 154-162, (http://ejournal.upi.edu/index.php/JER /article/viewFile/3119/2141, diakses 6 Februari 2017).

Daryanti, dkk. 2015. Peningkatan Kemampuan Penalaran IImiah Melalui Model Pembelajaran Inkuiri Terbimbing pada Materi Sistem Pernapasan Manusia. Jurnal Pendidikan 
Matematika dan Sains Tahun III, (Online), No. 2, Hal. 163-168, (journal.uny.ac.id/index.php/jpms/arti cle/download/10948/8204, diakses 8 Januari 2017).

Direktorat Pembinaan Sekolah Menengah Atas. 2017. Panduan Penilaian oleh Pendidik dan Satuan Pendidikan untuk Sekolah Menengah Atas. Jakarta: Kementerian Pendidikan dan Kebudayaan.

Faizah, N. 2010. Bimbingan Belajar dalam Meningkatkan Prestasi (Studi di Panti Asuhan Yatim Putra Islam Berbah Kabupaten Sleman Provinsi Daerah Istimewa Yogyakarta. Fakultas Dakwah. Universitas Islam Negeri Sunan Kalijaga Yogyakarta. (Online). Diakses pada 6 Mei 2017 di http://digilib.uin-

suka.ac.id/5109/1/BAB\%20I,IV,\%20DA

FTAR\%20PUSTAKA.pdf.

Firdaus, dkk. 2016. Pengembangan Perangkat Pembelajaran Sains Berorientasi pada Siklus Belajar 5E untuk Memberdayakan Keterampilan Berpikir dan Pemahaman Konsep Siswa SMP. Jurnal Ilmiah Pendidikan Biologi Bioscientist, (Online), Vol. 2, No. 1, Hal. 221-236, (http://ejournal.pkpsmikipmataram.or g/index.php/biologi/article/view/192, diakses 8 Januari 2017).

Hartati, T. A. W., dkk. 2015. Perbandingan Potensi Model Pembelajaran Berbasis Konstruktivis (Inkuiri Terstruktur dan Siklus Belajar 5e) dalam Memberdayakan Keterampilan Proses Sains dan Hasil Belajar Kognitif Siswa Berkemampuan Akademik Rendah. Prosiding Seminar Nasional XII Pendidikan Biologi FKIP UNS 2015.

Hosnan, M. 2014. Pendekatan Saintifik dan Kontekstual dalam Pembelajaran Abad 21. Bogor: Ghalia Indonesia.
Kunandar. 2011. Langkah Mudah Penelitian Tindakan Kelas Sebagai Pengembangan Profesi Guru. Jakarta: PT Rajawali Pers.

Krajcik, J. S. \& Czerniak, C. M. 2014. Teaching Science in Elementary and Middle School: A Project Approach, 4th edition. New York, NY: Routledge.

Lestari, S. 2011. Penerapan Model Pembelajaran Learning Cycle (LC 5E) Berpendekatan JAS pada Materi Sistem Ekskresi di SMAN 3 Salatiga. Skripsi FKIP Universitas Negeri Semarang.

Muhfahroyin. 2009. Memberdayakan Kemampuan Berpikir Kritis Siswa Melalui Pembelajaran Konstruktivistik. Jurnal Pendidikan dan Pembelajaran, (Online), Vol. 16, No. 1, Hal. 8893,(http://journal.um.ac.id/index.php/ pendidikan-danpembelajaran/article/viewFile/2611/5 94, diakses 6 Februari 2017).

Permendikbud Nomor 24 Tahun 2016 tentang Kompetensi Inti dan Kompetensi Dasar Pelajaran pada Kurikulum 2013 (Salinan).

Pratiwi, R. 2016. Penerapan Model Siklus Belajar $5 E$ pada Materi Sistem Ekskresi untuk Meningkatkan Hasil Belajar Siswa Kelas XI IPA 3 SMA Negeri 9 Kota Bengkulu. Skripsi tidak diterbitkan. Bengkulu: Pendidikan Biologi FKIP Universitas Bengkulu.

Purwanto, A. 2014. Implementasi Model Learning Cycle " $5 \mathrm{E}$ " Disertai LKS untuk Meningkatkan Aktivitas, Keterampilan Proses Sains, dan Hasil Belajar Biologi. Jurnal Pendidikan Biologi BIOEDUKASI, (Online), (http://fkip.ummetro.ac.id/journal/ind ex.php/biologi/article/viewFile/259/22 0, diakses 9 Januari 2017).

Putri, M. K. N. 2016. Peningkatan Kemampuan Penalaran dan Pemahaman Konsep Matematika Melalui Pembelajaran Learning Cycle 5E pada Siswa Kelas VII SMP Negeri 1 
Mojolaban Tahun Ajaran 2015/2016. Tabany, T. I. B. 2014. Mendesain Model Fakultas Keguruan dan IImu Pendidikan. Universitas Muhammadiyah Surakarta. (Online). Diakses pada 9 Januari 2017 di Wena, M. 2014. Strategi Pembelajaran http://eprints.ums.ac.id/44315/23/NA Inovatif Kontemporer Suatu Tinjauan. SKAH\%20PUBLIKASI.pdf. Jakarta: PT. Bumi Aksara.

Susanti, M. N. I. 2010. Statistik Deskriptif dan Induktif. Yogyakarta: Graha Ilmu. Pembelajaran Inovatif, Progresif dan Kontekstual. Jakarta: Prenadamedia Group.

Yudhistira, D. 2013. Menulis Penelitian Tindakan Kelas yang APIK. Jakarta: PT Gramedia Widiasarana Indonesia. 